\title{
Svend Skriver
}

Assistant professor ved Institut for Nordiske Studier og Sprogvidenskab, Københavns Universitet

\section{'Det var ikke særlig slemt at læse den'. En empirisk undersøgelse af romanen i klasserummet}

\section{Sammendrag}

Hvorfor er det krcevende at undervise i romaner? Artiklen besvarer spørgsmålet med udgangspunkt i en observation af en nordsjællandsk gymnasielærers undervisning af en 2.g. biotek-klasse i H.C. Andersens roman Lykke-Peer (1870/1984). I fire analytiske nedslag undersøges det specifikt, hvordan undervisningsgenstanden (i form af såkaldte genrevariabler) påvirker undervisningen, herunder læererens didaktiske prioriteringer samt elevernes reaktioner på genstanden og lererens udspil. Det litteraturdidaktiske case-studie er gennemført som en fokuseret observation (Hopkins 2009, s. 88-89) på baggrund af en åben pilot-observation af et tilsvarende undervisningsforløb og et teoretisk forarbejde (Skriver 2010). Et af de centrale resultater af undersøgelsen er den analytiske tydeliggørelse af, at genrevariablen den komplekse fortælling, ncermere bestemt afdcekningen af fortcellertypen, skaber de mest markante didaktiske udfordringer for lareren. På den baggrund forekommer det relevant at videreudvikle de didaktiske genveje og løsningsforslag i relation til fortcller-problematikken, som er fremlagt i en foreløbig form i Skriver (2010).

\section{En udfordrende undervisningsgenstand. Indledning}

Det er ikke let at undervise i romaner. Det ved enhver, der har prøvet. Romaner er typisk lange. Derfor er det mest åbenlyse problem, som møder underviseren da også ofte at få eleverne til at læse romanen. For hvordan motiverer man sine elever til at læse 100-300 siders skønlitteratur af pligt? Det er den længste og mest tidskrævende læselektie, en elev overhovedet kan møde på de gymnasiale uddannelser, men det er naturligvis langt fra den eneste didaktiske udfordring, som viser sig. Af samme grund tænker den typiske gymnasielærer sig da nok også om en ekstra gang, før han eller hun præsenterer eleverne for en roman. Det indtryk fik jeg under alle omstændigheder, da jeg tog kontakt til en række dansklærere for at få tilladelse til at observere deres undervisning. Det viste sig nemlig at være ganske svært at finde frem til en lærer, som skulle undervise i en roman inden for en overskuelig fremtid. Også i det lys forekommer det relevant at gennemføre en empirisk undersøgelse af de didaktiske vanskeligheder, som læreren stilles over for i forbindelse med romanundervisning. 
Artiklen giver et kort overblik over et observeret undervisningsforløb i H.C. Andersens roman Lykke-Peer (1870/1984) og præsenterer derefter fire koncentrerede analyser af mindre forløb og særligt perspektivrige interaktionssekvenser. På baggrund af de analytiske indsigter samt didaktiske refleksioner fra den forudgående teoretiske artikel afrundes artiklen med en resultatsfremlæggelse og en diskussion. Det er hensigten, at undersøgelsens resultater i en anden sammenhæng skal anvendes som udgangspunkt for en fremlæggelse af en række didaktiske genveje og praktiske løsningsforslag, som lærere kan anvende til at tackle undervisning i romaner. Her tænkes både på den i sammendraget nævnte fortællerproblematik og på de didaktiske udfordringer, som de øvrige undersøgte genrevariabler tydeliggør.

\section{Et litteraturdidaktisk casestudie. Materiale, metode og problemer}

Undersøgelsens form er et casestudie. Der er foretaget en fokuseret observation (Hopkins 2009, s. 88-89) af en lærers undervisning i H.C. Andersens roman Lykke-Peer i en biotek-klasse (2.g) på et nordsjællandsk gymnasium. Undervisningen strakte sig over 2 moduler á 100 minutter (inkl. 5 minutters pause i hver), som faldt på to på hinanden følgende fredage.

For bedst muligt at sikre validiteten af undersøgelsen har jeg søgt at påvirke undervisningens forløb mindst muligt. Det er læreren, som har valgt romanen, arbejdsformer, aktivitetsformer og rammerne for undervisningen. Det skal desuden tilføjes, at læreren ikke på forhånd er blevet informeret om undersøgelsens specifikke fokus.

Forud for observationsforløbet har jeg for at præcisere mit forskningsfokus foretaget en åben pilot-observation (Hopkins 2009, s. 86-87) af romanundervisning på et københavnsk hf-kursus (i foråret 2009) og i forlængelse heraf udarbejdet en teoretisk artikel (Skriver 2010) om romangenrens didaktiske potentialer samt de udfordringer den rejser i undervisningen. Jeg har samtidig anvendt Cohen et al. (2007) som centralt baggrundsværk i arbejdet med at håndtere materialet.

I forlængelse af den empiriske og teoretiske indsats har jeg under observationen og i det efterfølgende analytiske arbejde valgt at fokusere på, hvordan de særlige genrekarakteristika for romanen (de såkaldte genrevariabler) indgår i og påvirker undervisningen. De undersøgte genrevariabler er nærmere bestemt "den lange tekst" (altså romangenrens omfattende længde), "den komplekse fortælling", den "dybtgående personskildring" og den "bredt udfoldede verden" (Skriver (2010, s. 136-147).

De digitale optagelser af undervisningen (lyd og billeder) fra det nordsjællandske gymnasium er transskriberet og analyseret. Ud over mit primære fokus på genrevariabler har jeg i de koncentrerede analyser været særlig opmærksom på interaktionsstrukturen IRF (Initiation, Response og 
Follow-up) for bedst muligt at kunne begribe forløbet af klasserumsdialogen og hermed forbundet elevernes læringsprocesser. Jeg har i dette arbejde benyttet mig af Bundsgaard \& Hansens (2010) perspektivrige videreførelse af Sinclair og Coulthard (1975) og Wegerif (2004). Eftersom ærindet med undersøgelsen ikke er interaktionsanalytisk, er det samlede materiale dog ikke kodet efter disse mønstre.

I forhold til gruppearbejdet valgte jeg at koncentrere min opmærksomhed om en enkelt tilfældigt udvalgt gruppe, hvis notater er indsamlet og indgår i materialet til undersøgelsen. Hvad der foregik i de øvrige grupper, har jeg derfor ikke præcis viden om. Alt materialet er anonymiseret af forskningsetiske grunde.

I det følgende giver jeg et kort overblik over undervisningsforløbet og leverer i forlængelse heraf analytiske nedslag på fire store sekvenser, som på forskellig vis demonstrerer de særlige didaktiske muligheder eller udfordringer, som romanundervisningen rejser.

\section{Undervisningens forløb}

Undervisningen løb af stabelen over to fredage i november. Det var oprindeligt meningen, at den skulle have fundet sted længe før, men på grund af sygdom, travlhed med at nå det planlagte pensum samt elevernes årligt tilbagevendende 'Operation Dagsværk' blev den udskudt. En roman er typisk tidskrævende at undervise i og derfor også vanskelig at indpasse i den fortløbende undervisning. Læreren valgte som anført ovenfor at anvende 2 moduler á 100 minutter på forløbet. Det er under normale omstændigheder ikke en høj tidsmæssig prioritering af en roman, men ifølge læreren var der simpelthen ikke tid til mere. Undervisningen i romanen fungerede som afslutning på et forløb om 1800-tallet; og herfra var det vigtigt at komme videre med det næste forløb om sprog for at kunne nå det samlede planlagte program for året.

Den første morgen uddelte læreren allerførst i undervisningen et arbejdspapir med et mindre antal overskrifter og en lang række detaljerede underpunkter, som dels beskrev den stoflige progression for dagens undervisningsforløb ("Intro til romanen", "Romananalyse", "Personer", "Perspektivering”) dels i stikordsform angav de valgte arbejdsformer ("Fælles" og "Par/Gruppearbejde”). Arbejdspapiret tilbød med andre ord eleverne et overblik over den stoflige og arbejdsmæssige progression i forløbet.

Læreren begyndte selve undervisningen ved at spørge til elevernes umiddelbare reaktioner på romanen og åbnede derefter en generel eksistentiel diskussion i forlængelse af værket. Efter denne "Intro til romanen” gik læreren planmæssigt videre med "Romananalysen”, nærmere bestemt en gennemgang af centrale narratologiske aspekter ved værket. På den baggrund iværksattes gruppearbejdet. På forhånd formaliserede par af elever, som læreren tidligt i skoleåret havde sammensat i samarbejde med de øvrige medlemmer af klassens 
lærerteam, fandt sammen par og par i grupper på fire og arbejdede med spørgsmålene på arbejdspapiret.

Den anden undervisningsgang præcis en uge senere forløb som en klasserumsgennemgang af spørgsmålene på arbejdspapiret. De enkelte elever kunne her byde ind med de svar, som de havde arbejdet med ugen forinden i grupper. Forløbet blev afsluttet med en ganske kort skriveøvelse, hvor eleverne fik til opgave at sammenfatte pointerne fra dagens undervisning.

\section{Den dobbelte vækkelse}

Den centrale undervisningsgenstand var H.C. Andersens roman Lykke-Peer. Det er en kort roman fra 1870. Det har øjensynligt ikke voldt eleverne store vanskeligheder at læse den. Kun en enkelt af eleverne bemærker, at "nogle af ordene var lidt svære at forstå”. Den største didaktiske udfordring er da heller ikke af sproglig karakter, men af mentalitetshistorisk. Der er langt fra H.C. Andersens førmoderne 1800-tals bevidsthed til de unge biotek-elevers virkelighed anno 2010.

Med sin indledende spørgsmålsrække til elevernes "umiddelbare reaktioner" på romanen vælger læreren at fokusere på deres umiddelbare oplevelse af værket: "Var det en god bog? Var det en spændende bog? Var den værd at læse?” Det er tre åbne, generelle spørgsmål, som lægger op til en subjektiv værdidom. Elevernes reaktioner på romanen, hvoraf her er klippet tre ud af klasserumsdialogen, er tankevækkende:

”Den var meget langtrukken, og der skete ikke rigtig noget. Andet end man fik at vide, hvordan hans liv var stille og roligt (...), men altså der var jo ikke rigtig noget drama eller noget i den - noget højdepunkt. (...) Det var også fint nok at læse, men det var ikke noget, der fangede.”

"Som 'Camilla' siger, spændingskurven er meget flad i det. Og så er der lige til sidst, at de lige har det der med koncerten og med Aladdin. Og så afrunder de den bare ved at han dør fra dem [knips] så er han død.”

”Det var ikke særlig slemt at læse den.”

Den første reaktion er styrende. 'Camilla' oplever H.C. Andersens roman som "meget langtrukken" og sætter dermed ord på elevernes fremmedhed over for værket. Hendes synspunkt vinder hurtigt genklang blandt de øvrige elever. "Spændingskurven er”, som en dreng bemærker det i en uddybende kommentar, "meget flad i det". Det sidste er en sandhed med modifikationer. For et klassisk litteraturanalytisk blik er spændingskurven jævnt stigende med en række mindre udsving og kulminerer med de afsluttende dramatiske begivenheder, men 
elevens optik er en anden. Det storladne afsluttende drama, hvor hovedpersonen Peer dør på scenen i sin karrieres højdepunkt, oplever den førnævnte dreng nærmest som en bagatel: "[knips] så er han død.” I flere af deres umiddelbare reaktioner efterlyser eleverne indirekte en mere eksplicit spænding. De savner øjensynligt litteræer suspense.

Særligt tankevækkende er den sidste af de tre citerede reaktioner, "Det var ikke særlig slemt at læse den”, der fremsættes af en pige, som i øvrigt ikke markerer sig i klasserumsdiskussionen. Med formuleringen "ikke særlig slemt” indikerer hun, at hun havde forventet en langt mere negativ læseoplevelse. Hendes måde at sprogliggøre sin oplevelse af værket på kunne næsten minde om en beskrivelse af et lettere ubehageligt tandlægebesøg: 'Det var i virkeligheden ikke særlig slemt. Gør det bare. Det er rart at få det overstået.'

Med sine åbne generelle spørgsmål giver læreren eleverne mulighed for at italesætte deres æstetiske fremmedgjorthed over for værket. Samtidig lægger han så blødt ud, at mange elever på trods af det ugunstige tidspunkt (fredag morgen) melder sig frivilligt med reaktioner. Han 'vækker' dem billedlig talt af morgensløvheden. Herfra består lærerens arbejde i at bygge bro mellem eleverne og værket, så æstetisk fremmedgørelse kan forvandles til æstetisk fremmederfaring. Det gør han ved hjælp af et eksemplarisk fagdidaktisk spørgsmål, som tydeligt er tænkt med udgangspunkt i H.C. Andersens roman.

Han spørger eleverne om, hvad "der bestemmer et menneskes livsforløb", eller med de efterfølgende mere specifikke formuleringer, "Hvad er det, der (...) for os moderne mennesker gør os til dem, vi bliver til? Eller (...) bestemmer vores udvikling?”

Når spørgsmålet og de uddybende underspørgsmål er relevante i forhold til romanen Lykke-Peer, er det, dels fordi Andersen har brugt så relativt meget plads på at skildre karakteren Peer og hans menneskelige udvikling, dels fordi romanen i så høj grad tager stilling til, hvad der bestemmer karakteren Peers udvikling. I et romandidaktisk perspektiv er det ekstra interessant, at læreren på denne måde sætter en af de førnævnte genrevariabler, nemlig den dybtgående personskildring, i spil i relation til elevernes generelle forståelse af verden. Ved at trække spørgsmålene ud af romanen og stille dem specifikt i forhold til elevernes oplevelse af tilværelsen, vækker han deres engagement og får skabt stor aktivitet blandt dem. Han udnytter en del af genrens didaktiske potentiale og rammer eleverne rent.

Det er bemærkelsesværdigt, at en række af de elever, som ikke har været på banen i den allerførste del af lektionen, nu melder sig med reaktioner, herunder tre drenge. De første fire reaktioner lyder som følger:

”Jeg vil sige sådan noget som beslutsomhed og viljestyrke, fordi alle valg er åbne. Man kan nærmest, hvad man vil i dag. Det er bare, om man vil lave noget for det.” 
”Jeg tror også, at der er en del held, tage de rigtige valg."

”Jeg tror også, at det har meget med opdragelsen at gøre, hvilken opvækst man har fået, hvordan man bliver opdraget.”

"Uddannelse."

Eleverne føler sig øjensynligt mere på hjemmebane, når stoffet som her er almenmenneskeligt og ikke fagligt (læs: sprogligt, litteraturanalytisk eller litteraturhistorisk). Her er det 'ufarligt' at byde ind, man kommer ikke til at sige noget forkert. Læreren skaber dermed en åbning for de elever, der i første omgang ikke bød ind og som måske ellers ikke ville byde ind i forhold til en strengt faglig kontekst. Ved samtidig systematisk arbejde med optag af elevernes kommentarer, der alle noteres på tavlen, sikrer læreren, at også de elever, som efter den begrænsede kontekst at dømme er svagt præsenterende, får en tydelig placering i klasserumsdialogen.

Herfra bevæger læreren sig videre i forløbet ved at lade eleverne anskue undervisningsgenstanden i lyset af deres mange reaktioner på det almenmenneskelige spørgsmål. Han beder eleverne om, at sammenligne deres synspunkter på, hvad der bestemmer et menneskes livsforløb, med de faktorer eller forhold, som i romanen bestemmer karakteren Peers livsforløb. Det skaber en livlig debat. En af pigerne bemærker fx:

Hans viljestyrke gør jo også, at han kommer frem, fordi det kunne jo lige så godt være, at man siger, fordi han er fattig, så kan han ikke komme frem i verden, men det er han lidt ligeglad med.

Den sidste del af udsagnet rummer en væsentlig indsigt $\mathrm{i}$ forhold til karakteristikken af Peer. Han er nemlig - som læreren da også bemærker det i sit 'optag' af elevens kommentar - ret ligeglad med, hvad omgivelserne mener. Lærerens stemmeføring demonstrerer tydeligt, at han er positivt overrasket. Måske havde han ikke tænkt på det selv, måske er han overrasket over elevens præstation. Under alle omstædigheder kan man som tilhører mærke, at eleven efter lærerens mening her har ramt noget centralt. Optaget er autentisk. Og den analytiske betragtning dukker i øvrigt op på ny i den efterfølgende lektion i en større analytisk kontekst.

Med sin fagdidaktiske spørgeteknik stiller læreren skarpt på et koblingspunkt mellem undervisningsgenstanden og elevernes horisont. Han bygger med andre ord bro mellem elevernes oplevelse af tilværelsen og romanens fortolkning af samme og skaber et solidt grundlag for, at eleverne angriber romanen, som de i udgangspunktet oplevede som kedelig og "meget langtrukken”, på en engageret og levende måde. Han mindsker deres æstetiske fremmedgørelse og giver dem blik for dimensioner af værket, som de umiddelbart kan relatere til. 
Efter et mindre antal indlæg fra eleverne vælger læreren dog at stoppe debatten og bevæge sig videre $\mathrm{i}$ en ny sekvens (formentlig på grund af tidspresset) og udnytter dermed ikke potentialet i situationen fuldt ud, men har under alle omstændigheder skabt et godt udgangspunkt for elevernes fortsatte arbejde med romanen.

Det skal bemærkes, at læreren gentager manøvren ved i en efterfølgende sekvens at spørge eleverne, hvad lykke er, eller hvad der gør et menneske lykkeligt. Igen er der tale om et centralt aspekt ved romanen, som trækkes fri af den litterære kontekst og almengøres, så eleverne umiddelbart kan relatere til det. På den baggrund vender eleverne så atter tilbage til værket og anskuer det i lyset af deres almene udsagn.

\section{”Lidt mere litteraturagtigt”. Den komplekse fortælling}

Efter den åbne og elevorienterede begyndelse på lektionen skifter læreren nu didaktisk modus og koncentrerer opmærksomheden fuldt ud om den primære undervisningsgenstand: romanen. Han markerer skiftet eksplicit med de følgende bemærkninger, som på en gang rammesætter situationen, introducerer arbejdsemnet og udtrykker det indledende spørgsmål til eleverne:

Lærer: Okay, lad os gå i gang med selve teksten (skriver på tavlen). Jeg starter med at spørge, og det, jeg starter med at spørge til fortællertype, hvorfor... Nu tager vi det lige lidt mere litteraturagtigt. Hvorfor er det vigtigt, at vi får at vide, hvilken fortællertype det er, man har med at gøre? Hvorfor er det altid vigtigt?

Med formuleringen "lidt mere litteraturagtigt" indikerer læreren, at han og eleverne nu skal tæet på teksten på en klassisk litteraturvidenskabelig facon. Emnet som undersøges, 'fortællertypen', er kompliceret. Det bliver ikke mindre kompliceret af, at den litteraturvidenskabelige forskning har præsenteret et utal af mulige tilgange, analyse-modeller og begrebsapparater. At bestemme en fortællertype i en given tekst udfordrer derfor typisk både lærer og elever. I forhold til en roman vanskeliggøres sagen yderligere, fordi tekstmassen, som man analytisk skal overskue, er så meget større end i fx en novelle. Den førnævnte genrevariabel, den komplekse fortclling, påvirker med andre ord denne del af undervisningen markant. Eleverne er nu mærkbart mere usikre end før. Det fremgår af den følgende transskriberede interaktionssekvens, hvor IRFstrukturerne er markeret i parenteserne:

(Initiation) Lærer: (...) Og fortælleren her, hvad er det for en fortællertype, vi har med at gøre i den her historie? Pia?

(Response) Pia: En tredjepersonsfortæller. 
(Follow-up) Lærer: Jah, der har vi jo sådan lidt forskellige afdelinger af tredjepersonsfortællere, man kan sige, vi kan, vi kan sådan, jeg tegner lige lidt oplysning herude, vi kan sige sådan i den ene ende af skalaen, der har vi den registrerende eller den behavioristiske eller objektive, registrerende (skriver), og i den anden ende der har vi den alvidende, og så kan vi have sådan en personbunden fortæller, der måske ligger lidt mere på midten et eller andet sted (skriver).

(I) Lærer: Hvor er vi henne her, hvad er det for en type fortæller, vi har her? (...)

(R) Christina: Er det ikke en alvidende tredjepersonsfortæller?

(F) Lærer: Skal vi, hvad, du spørger, jeg spørger (griner).

(R) Christina: Nej, jeg mener, det er en tredjepersons alvidende fortæller (sidste ord udtales tøvende)

(F/I) Lærer: Det er en alvidende fortæller, hvad er det nu, der er karakteristisk for den alvidende fortæller, kan du huske det?

Lærerens reaktion på 'Pias' svar er karakteristisk for denne del af undervisningsforløbet. Han evaluerer hendes respons med formuleringen "Jah, der har vi jo sådan lidt forskellige afdelinger af tredjepersonsfortællere (...)", som med sit underspillede "Jah" markerer, at hun er på sporet af det korrekte svar. For at øge 'Pias' og de øvrige elevers mulighed for at forstå sagsforholdet korrekt fortsætter han sætningen og sin taletur med at formidle konkret narratologisk viden, som skal ruste eleverne til at svare på det efterfølgende lukkede, specifikke opfølgende spørgsmål.

Interaktionen bærer tydeligt præg af høj lærerstyring. Læreren kontrollerer og dominerer samtalen. Det er bemærkelsesværdigt, at 'Christina', som melder sig på banen efter 'Pia', fremsætter sit i øvrigt udmærkede svar som et spørgsmål. Hun er usikker på sit svar og tøver. Derfor reagerer læreren med en metakommentar. Med formuleringen "Skal vi, hvad, du spørger, jeg spørger" signalerer han, at samtalen er faldet ud af det af ham valgte IRF-interaktionsmønster, dvs. 'jeg' (læreren) spørger, 'du' (eleven) svarer og 'jeg' evaluerer og følger op. I samme nu tager Christina mod til sig og fremsætter sit svar som en konstatering, som hun dog vælger at relativere med forsigtighedsmarkøren ”jeg mener".

Interaktionssekvensen tydeliggør den komplekse fortellings faglige fordringer og sværhedsgrad. I modsætning til de forudgående sekvenser med de åbne generelle spørgsmål om, hvad "der bestemmer et menneskes livsforløb”, og hvad lykke er, er eleverne tydeligvis klar over, at undervisningen faktisk er blevet "lidt mere litteraturagtig". De er mere eller mindre bevidste om, at man let kan svare forkert på de teknisk betonede spørgsmål, som fordrer tekstnært tænkearbejde.

Det er tydeligt, at læreren i langt højere grad end i den forudgående del af undervisningen benytter sig af lukkede og specifikke spørgsmål og former dialogen i relativt hårdt styrede IRF-forløb. Grundet den komplekse fortcellings 
sværhedsgrad og måske også den høje styringsgrad skal han kæmpe for at få eleverne til at svare. Det er efter observationsmaterialet at dømme målet med forløbet at få fortæller-typen og -positionen og handlingsforløbet afdækket. For at opfylde målet i sin helhed må læreren flere gange selv tage over og uddybe elevernes svar i lange fagligt præciserende taleture. Efter gennemgangen af fortællertypen retter læreren opmærksomheden mod "den fortalte tid" og "handlingsforløbet", som de i fællesskab ridser op i grove træk. På grund af tidspresset (den første pause nærmer sig) er styringen fortsat høj, men emnet er mere enkelt at gå til for eleverne, som derfor besvarer lærerens spørgsmål med langt mindre tøven. Stemningen bliver på ny mindre anspændt.

\section{Præstationsminimalisme i gruppearbejdet}

Gruppearbejdet sættes i gang efter pausen midt i første lektion. I sin korte optakt til gruppearbejdet understreger læreren vigtigheden af, at alle "deltager i diskussionen” samt at alle skriver ned, hvad man taler om i gruppen. På den måde forsøger han at sikre, at samtlige elever tager aktivt del i undervisningen og forbereder sig grundigt til klasserumsgennemgangen den efterfølgende fredag. Derudover forklarer læreren i forlængelse af spørgsmålene på det udleverede arbejdspapir, at eleverne skal undersøge, hvilken funktion de forskellige bipersoner har i teksten samt vigtigheden af, at eleverne noterer sig de tekststeder, som de opfatter som centrale for deres analyse.

Gruppen som observeres består af to drenge og to piger. De arbejder alt i alt i 39 minutter. Aktivitetsniveauet er ikke højt. De bevæger sig langsomt ind i spørgsmålene og underpunkterne til dem og noterer undervejs uden at blive færdige med alle spørgsmålene. Den følgende interaktionssekvens, som er fra den første del af gruppearbejdet, giver et illustrativt indtryk af gruppens arbejde:

'Henrik': Flytter farmoren egentlig ind, da faren dør?

'Julianne': Det virker det lidt sådan.

'Henrik': Ja, ikke?

'Julianne': Hun bor sammen med dem.

'Marianne': Hun er der i hvert fald altid, ik.

'Henrik': Jo, jamen jeg tror nærmest hun flytter ind, da han dør.

'Martin': Hun flytter ind, da han døde?

'Henrik': Ja, det tror jeg.

(lang pause)

'Henrik': Det står på side 10.

'Julianne': At hun flytter ind eller hvad?

'Henrik': Der står bare, at hun bliver der.

'Julianne': Nåh. 
'Henrik' initierer forløbet med sit spørgsmål om karakteren Peers baggrund til de andre og besvarer det selv endeligt med sin nøjagtige sidehenvisning. Samtalen er som gruppens dialog i øvrigt præget af korte, fakta-afklarende sætninger. Eleverne arbejder i fællesskab på at få styr på og nedskrive, hvad der konkret foregår i romanens handlingsforløb. Derfor er størstedelen af elevernes udsagn refererende. De bevæger sig kun i begrænset omfang op på et analytisk og/eller fortolkende niveau. Det er samtidig karakteristisk, at de ikke forfølger deres analytiske iagttagelser og går i dybden med dem.

Romangenrens føromtalte omfattende længde (den lange tekst), som tillader forfatteren at udfolde en dybtgående personskildring og forbundet hermed et stort persongalleri, viser sig på ny som en markant didaktisk udfordring. Ikke mindst fordi de mange karakterer indgår i en række forskellige miljøer, som eleverne nødvendigvis skal danne sig et overblik over for at kunne forstå karaktererne. Her spiller genrevariablen den bredt udfoldede verden altså også ind.

Materialet, som eleverne arbejder med, er omfangsrigt. Læreren lægger op til, at eleverne i arbejdet skal forholde sig til mindst 4-5 karakterer og kan vælge at forholde sig til op til 12 karakterer. I øvrigt med den ikke uvæsentlige klausul, at de karakterer og spørgsmål, eleverne ikke når i gruppearbejdet, skal færdiggøres hjemme.

Selvom det er en kort roman, er det stadig en stor tekst i forhold til en undervisningssituation. Hvis man - som læreren her gør det - ønsker, at eleverne skal have et reelt overblik over tekstens bredt udfoldede verden, skal de nødvendigvis bruge en del energi på et refererende niveau, sådan som man ser, at de gør det i citatet ovenfor. Når der så samtidig ikke har været mulighed for at afsætte mere tid til arbejdet med romanen, får den valgte fremgangsmåde den konsekvens, at eleverne i grupperne skal arbejde både målrettet og determineret for at nå op på et kvalificeret analytisk niveau, som læreplanen for dansk (stx), der er den gældende lovgivningsmæssige ramme for undervisningen, fordrer. Det gør de fire observerede elever som allerede antydet ikke. Man har i den danske didaktiske debat brugt begrebet præstationsminimalisme som betegnelse for arbejdsprocesser, hvor elever bevidst kun indfrier minimumskravene. Begrebet kan med en vis rimelighed også anvendes her. De fire elever laver mere eller mindre bevidst akkurat så meget til hvert punkt, som de vurderer, at læreren som minimum vil forvente af dem, og stopper derefter arbejdsprocessen og går videre til næste punkt.

Det er da også tankevækkende at sammenholde den ovenstående interaktionssekvens med det korte tidsrum, hvor læreren er i kontakt med gruppen og griber aktivt ind i deres arbejdsproces. Her følger et uddrag af transskriptionen. Lærerens spørgsmål retter sig mod karakteren Felix:

(I) Lærer: Ja, hvilken funktion skal han have i den her tekst, Felix?

(R) 'Martin': Hvilken hvad? 
(Initiation/Follow-up) Lærer: Hvilken funktion? Hvorfor har H.C. Andersen opfundet ham så at sige?

(R) 'Martin': Altså jeg...

(I/F) Lærer: Og sågar født samme dag, samme sted, dog nedenunder.

(R) 'Henrik': Det ...

(I/F) Lærer: Ja, en af jer bare.

(R) 'Julianne': For at skabe modsætninger.

(I) Lærer: Ja, hvordan?

(R) 'Julianne': Altså rig og fattig.

(F) Lærer: Ja.

(R) 'Henrik': Ja, så kører de parallelt.

(I/F) Lærer: Så kører de parallelt?

(R) 'Henrik': Ja, deres udvikling kan man ligesom perspektivere til hinanden.

Læreren sætter med det samme ind på et højere taksonomisk niveau. Han vil gerne have eleverne til at reflektere analytisk over karakteren Felix. Det centrale analytiske spørgsmål om 'funktion' står i arbejdspapiret, eleverne var netop kommet frem til dette punkt, men var ikke gået i gang med det. Eleverne har tydeligvis ikke let ved at forholde sig til problemstillingen. Den er krævende. Læreren fremsætter sin initierende appel 4 gange.

'Martin' beder først om en uddybning. Den leverer læreren. Derefter forsøger 'Martin' sig med et bud, men bliver afbrudt af læreren som på ny uddyber sit spørgsmål. Så forsøger 'Henrik' at byde ind, men går i stå i sin sætning, hvorpå læreren igen tager ordet og uddelegerer det til 'Juliane', der leverer en indholdsmæssig kvalificeret respons. Nu er eleverne i gang. Og 'Henrik' overtager ligefrem initiativet, idet han selvstændigt viderefører 'Juliannes' analytiske iagttagelse og når frem til den centrale pointe, at karakterernes respektive udvikling skal perspektiveres "til hinanden."

Som det fremgår af transskriptionsuddraget leverer eleverne korte, men præcise analytiske karakteristikker. Ved vedblivende at fastholde en analytisk tilgang lykkes det efterfølgende for læreren at få alle fire medlemmer af gruppen til at reflektere analytisk over teksten. Læreren bryder elevernes præstationsminimalistiske arbejdsmønster.

Så snart læreren går videre til den næste gruppe, 'synker' de fire elever imidlertid igen ned på et rent refererende niveau, hvor de i øvrigt forbliver i den resterende tid. De forholder sig ikke på ny til spørgsmålet om karakterernes funktion, selvom arbejdsarket lægger op til det. Det er ligeledes karakteristisk, at kun pigerne noterer de analytiske iagttagelser fra samtalen med læreren ned på sit papir. 'Henrik' og 'Martin' fornemmer tilsyneladende ikke vigtigheden af disse iagttagelser, som ellers i et litteraturanalytisk perspektiv er fuldstændig centrale.

Det er en velkendt erfaring blandt dansklærere, at det kan være forbundet med store vanskeligheder at få elever til at tage springet fra et refererende til et analytisk niveau. De fire elevers arbejde demonstrerer imidlertid, at problemet 
sættes på spidsen under gruppearbejde med romaner som genstand. Eleverne bruger lang tid på alene at få hold på de karakterer og miljøer, som indgår i romanens bredt udfoldede verden. Under arbejdet med en roman kan eleverne lettere 'krybe i ly' på det refererende niveau, fordi der typisk er langt mere at forholde sig til dér, end hvis de fx arbejder med et digt eller en novelle.

\section{En analyse skal i hus}

Det andet modul ugen efter forløber som nævnt ovenfor som en klasserumsgennemgang af resultaterne fra gruppearbejdet. Læreren åbner ballet med at harpunere en elev, 'Ismael', som han beder om kort at opridse, hvad de talte om den forrige lektion, inden gruppearbejdet begyndte. 'Ismael' checker sine notater på sin bærbare pc og fortæller ganske kort om begrebet "lykke”, de "faktorer, der styrer ens livsforløb" og "handlingsforløbet".

Kommet så vidt leder læreren sine elever videre ind $\mathrm{i}$ analysen med en lang række spørgsmål til teksten, der enten er eksplicitte omformuleringer af spørgsmålene fra arbejdsarket eller ligger tæt op ad disse.

Undervisningen bevæger sig nu væk fra genrevariablen den komplekse fortcelling, som akkurat lige blev berørt af 'Ismaels' repetition af handlingsforløbet. I stedet koncentrerer læreren sin og elevernes opmærksomhed om karakteristikken af Peer. På baggrund af det forudgående gruppearbejde benyttes ca. 27 minutter ud af de ca. 42 minutter, som første del af den anden lektion varer, til at få lavet en personkarakteristik af Peer med en kort digression til romanens forståelse af Gud som eneste afbrydelse. Ud fra et kvantitativt parameter er det dermed karakteristikken af den centrale karakter og hermed forbundet genrevariablen den dybtgående personskildring som vægtes højest i lektionen.

Klasserumsdialogen er præget af en relativt høj grad af lærerstyring. Ved hjælp af spørgsmål, fremsættelse af egne iagttagelser samt feedback og followup på elevernes svar styrer læreren målrettet eleverne gennem karakteristikken af Peer og gennemfører i løbet af de 27 minutter en relativt nuanceret analytisk beskrivelse af Peer og hans funktion i romanen.

Formelt domineres undervisningen af IRF-strukturer og forskellige varianter af samme. Man har ofte direkte eller indirekte kritiseret læreres brug af IRFstrukturen i undervisningen. Wegerif (2004) bemærker i den forbindelse:

Many have noted that the IRF structure allows the teacher to keep control of the direction of the interaction with students. The student's input is always framed by the teacher's prompts and evaluations. As a result the IRF exchange structure has been criticised by those that claim that it controls students too much and prevents them from thinking for themselves and asking their own questions 
Af samme grund har Wegerif som et brugbart alternativ foreslået IDRFstrukturen (Initiation, Discussion, Response, Follow-up), der inkorporerer diskussion mellem eleverne (ibid.). Som allerede antydet prioriterer den observerede lærer imidlertid ikke IDRF-strukturen eller tilsvarende strukturer i klasserumsgennemgangen. Det skal ikke forstås som udtryk for en negativ vurdering af lærerens indsats, men alene som beskrivelse af det faktiske forløb. Det er som oftest en del lettere at foreslå konstruktive, tidskrævende didaktiske løsninger end at gennemføre dem i praksis under tidspres.

I første del af den forudgående lektion har læreren skabt rum for elevernes selvstændige udfoldelser med sine indledende åbne, generelle spørgsmål samt deres indbyrdes samtaler og diskussioner i det efterfølgende gruppearbejde. Han kunne have valgt at fortsætte denne elev-aktiverende linje. Fx ved at lade eleverne lynhurtigt opsummere deres synspunkter på Peer i de på forhånd organiserede par inden besvarelsen af hvert spørgsmål.

Når han ikke desto mindre vælger at lade såvel denne del som resten af klasserumsgennemgangen dominere af lærer-spørgsmål, elev-svar og lærerrespons, er den altoverskyggende grund, tror jeg, den snævre tidsramme. Og her er romanens dybtgående personskildring reelt en didaktisk udfordring. For eleverne har mange relevante og interessante iagttagelser og læreren mange væsentlige kommentarer, som skal indreflekteres for at fuldende deres fælles analytiske portræt af Peer. Efter dette tidskrævende arbejde kommer så overbliksgennemgangen af alle de mange bipersoner, som hver især har mere eller mindre fremtrædende roller og indgår på forskellig i romanens bredt udfoldede verden. Endelig venter fortolkningen af værket inklusiv den litteraturhistoriske perspektivering. Alt det skal nås i løbet af lidt under 100 min.

Inden for den givne tidsramme kunne læreren godt have givet eleverne plads til i ro og mag at udfolde egne selvstændige analytiske refleksioner over romanen, men de ville næppe have nået at være kommet igennem alle de planlagte punkter, hvis ikke læreren havde kontrolleret diskussionerne så markant, som han gjorde. Det faglige mål, som læreren prioriterer højest, er øjensynligt at få den samlede analyse af romanen i hus. Det er for ham ensbetydende med først at få repeteret "lykke"-begrebet, de "faktorer, der styrer ens livsforløb" samt "handlingsforløbet" og dernæst at få eleverne til via deres svar at nå frem til en færdig analyse af hovedpersonen og bipersonenerne samt romanens fortolkning af genibegrebet, der inddrages som en afsluttende litteraturhistorisk perspektivering. Hertil hører, at læreren selv formidler evt. 'manglende' dele af den samlede analyse, som eleverne ikke formår at italesætte på baggrund af hans spørgsmål. Begge lektioner er tilrettelagt med dette mål for øje. Det er dog karakteristisk, at den første lektion rummer to større zoner, hvor eleverne kan reflektere relativt frit over romanen. I anden lektion, hvor det samlede forløb skal afrundes, er tidspresset naturligt nok større.

Overordnet set forløber undervisningen i anden lektion fra lav styring til høj styring. Læreren øger groft sagt sin kontrol med interaktionen i klasserummet, jo 
tættere han kommer på slutpunktet. Det er nok en type af forløb de fleste undervisere vil kunne nikke genkendende til. Den sidste del af en lektion kan let blive ganske hektisk, når man er opsat på at nå igennem et planlagt stof.

Man kan så overveje, hvilke konsekvenser det får for undervisningen og elevernes læring, at læreren vælger at prioritere personkarakteristikken og dermed romanens "dybtgående personskildring” så højt i anden lektion.

På baggrund af observationen vil jeg hævde, at han opnår en umiddelbart imødekommede undervisning. For eleverne i denne klasse opleves det tydeligvis lettere at levere kvalificerede bidrag til en karakteristik af Peer end til en karakteristik af romanens fortæller. Sammenholdt med det korte forløb om fortæller-typen er de her langt mindre tøvende i deres fremfærd. Også i forhold til bipersonerne og miljøerne melder de sig med mange bud, ideer og iagttagelser.

Det hænger sammen med det forhold, at et undervisningsforløb, som lægger vægt på den dybtgående personskildring og den bredt udfoldede verden, typisk også indbyder eleverne til at bidrage med refererende udsagn. I et undervisningsforløb med fokus på den komplekse fortcelling er det derimod kun muligt at referere fra handlingsforløbet, mens fx beskrivelsen af fortæller-type, fortæller-position og relationen mellem fortalt tid og fortælletid fordrer en høj grad af analytisk indsigt samt en vis beherskelse af et narratologisk begrebsapparat. I præcis den forstand bliver indholdet altså sværere og mere vanskeligt tilgængeligt for eleverne, hvis man som underviser fokuserer på den komplekse fortcelling.

I dette tilfælde lægger læreren imidlertid stor vægt på at fastholde og styrke elevernes analytiske tilgang til teksten i arbejdet med karakteristikken af Peer. Det fremgår mange steder af transskriptionen. Fx et sted hvor læreren samler op på eleven 'Anders' iagttagelser med følgende ordvalg: "Anders, du siger, at han har en stærk vilje, hvor ser du det henne?" Underforstået: hvor ser du det henne $i$ teksten. Set i lyset af konteksten er det tydeligt, at læreren anerkender 'Anders', synspunkt og lægger op til, at han skal kvalificere og underbygge det analytisk, hvad han da også efterfølgende gør. Med denne fremgangsgåde sikrer læreren relativt konsekvent, at karakteristikken af Peer overalt, hvor det er muligt, begrundes med analytiske iagttagelser. Det er dog samtidig muligt for analytisk svagt præsterende elever at byde ind med rent refererende iagttagelser.

Når læreren tydeligt prioriterer at bibringe eleverne en forståelse af romanens dybtgående personskildring nedprioriteres imidlertid også en række andre stoflige elementer. Sådan må det nødvendigvis være inden for en snæver tidsramme.

I den del af første lektion, hvor undervisningen samlede sig om den komplekse fortcelling, blev eleverne præsenteret for en udlægning af romanens fortæller-type og handlingsforløbet samt en teoretisk tilgang til fortæller-typer, som læreren formidlede direkte. Det er imidlertid et åbent spørgsmål, hvor dyb elevernes forståelse af lærerens fortælleteoretiske pointer er. Det fremgår klart af 
de aktive elevers svar, at flere af dem forstår ganske meget, men hvad med de mange elever som forholder sig tavst og afventende i situationen? Det kan hverken læreren eller jeg svare præcist på. Den valgte prioritering får også den konsekvens, at der er meget kort tid til den afsluttende litteraturhistoriske fortolkning, der samtidig står som afrunding af det omfattende forløb om romantikken, som det observerede romanforløb indgår i. For at nå rundt om fortolkningen er læreren nødt til at præsentere sin egen mesterlæsning i en form for miniforelæsning, som indlejres i interaktions-sekvenserne. Der er simpelthen ikke tid til, at eleverne induktivt kan udvikle og udfolde selvstændige samlede fortolkninger.

\section{Resultater og diskussion}

Analysen af observationsmaterialet tydeliggør, at de enkelte elementer af romangenren påvirkede undervisningen i forskellig grad. Det interessante er naturligvis, hvordan de undersøgte fire genrevariabler påvirkede undervisningen, eller mere præcist hvilke synlige udfordringer de rejste i undervisningen.

Det mest overraskende resultat var, at størstedelen af eleverne at dømme efter deres spørgsmål, kommentarer og iagttagelser i undervisningen øjensynligt havde læst romanen. Genrevariablen den lange tekst påvirkede derfor kun i begrænset omfang undervisningen på den mest direkte måde. Det er dog samtidig klart, at det mindretal af elever, som efter lærerens og observatørens vurdering ikke havde læst romanen, må formodes at have fået et langt mindre læringsmæssigt udbytte af undervisningen end de øvrige.

Den af variablerne, som skabte de mest markante udfordringer i undervisningen, var den komplekse fortælling, nærmere bestemt afdækningen af fortæller-typen. Man kan ikke levere en egentlig analytisk karakteristik af en given fortæller uden i et vist omfang at beherske relevant fagterminologi. Og her var eleverne ikke på hjemmebane. De tøvede og havde svært ved at nå frem til de betegnelser, som læreren ud fra et litteraturfagligt synspunkt ønskede at få hæftet på fortælleren. Efter observationerne at dømme oplevede de emnet som abstrakt og svært håndgribeligt. Samtidig er det, hævder jeg, svært at overskue en så omfattende skønlitterær tekst ud fra et fortælleteoretisk perspektiv, hvis man ikke nøje har registreret spor af fortælleren i teksten undervejs i sin læseproces. En så avanceret læsestrategi kan man imidlertid på ingen måde forvente, at en typisk gymnasieelev gør brug af på eget initiativ. Det havde eleverne da efter alt at dømme heller ikke gjort. Når læreren derfor spurgte, "hvad er det for en fortællertype, vi har med at gøre i den her historie?", skulle eleverne reelt foretage et stort analytisk og tankemæssigt spring for at svare. Dertil kommer, at læreren øjensynligt på grund af stort tidspres ikke prioriterede emnet højt hverken tidsmæssigt eller didaktisk. Det indgik som et punkt i undervisningen, der ikke efterfølgende blev refereret tilbage til eller på anden 
vis inddraget i forløbet. Han prioriterede det dog højt nok til at gennemgå det kort og signalerede også eksplicit, at det var væsentligt. Det hører med til historien, at eleverne tidligere havde arbejdet med fortæller-problematikken angiveligt i flere forskellige sammenhænge, men at det på undervisningstidspunktet, så vidt jeg kunne forstå af situationen, var et godt stykke tid siden, at de sidst havde beskæftiget sig med den.

Den dybtgående personskildring var den af genrevariablerne, der blev prioriteret suverænt højest i undervisningen. Den dannede baggrund for sekvensen om spørgsmålet, om hvad "der bestemmer et menneskes livsforløb", som læreren havde trukket ud af teksten for at bygge bro til elevernes oplevelse af livet og verden. Gennem denne optimale udnyttelse af genrens didaktiske potentiale vakte han reelt elevernes interesse for den 'langtrukne' tekst. Den dybtgående personskildring dominerede desuden gruppearbejdet og 2. lektion og udgjorde dermed en rød tråd i det samlede undervisningsforløb.

I tæt tilknytning hertil var variablen den bredt udfoldede verden, som dog kun indgik, når personskildringen skulle uddybes. Som allerede nævnt muliggør undervisning med fokus på den dybtgående personskildring og den bredt udfoldede verden en høj grad af referat. At det også i praksis forholdt sig sådan blev i høj grad synligt i det observerede gruppearbejde. I udgangspunktet er et undervisningsforløb baseret på disse variabler let at gå til for eleverne, men de rejser den markante udfordring for læreren, at han eller hun skal motivere eleverne til at tage springet fra et refererende til et analytisk niveau. Her skal læreren altså gå ind og sikre at eleverne når frem til analysen. Det arbejdede den observerede lærer da også målrettet på.

Man kan nu spørge, hvad disse resultater betyder, eller med andre ord hvilke didaktiske konsekvenser man kan drage af undersøgelsen.

Selvom det øjensynligt har voldt eleverne færre besværligheder end forventet at få læst teksten, giver det forhold, at et mindre antal elever efter lærerens og observatørens vurdering at dømme ikke havde læst teksten god grund til at reflektere over, hvordan man kan hjælpe alle eleverne i en klasse i gang med at læse en roman-lektie og faktisk få dem til at læse den. En løsning kunne være at lade eleverne opnå fortrolighed med en eller flere læsestrategier, som kan støtte dem i læseprocessen (jf. Skriver (2010)). Man kan dog overveje om man ikke ved yderligere undersøgelser og systematisk gennemarbejdning af data kan nå langt videre end dette.

I forhold til den komplekse fortcelling er det observerede forløb næppe enestående. Mange litteraturundervisere vil utvivlsomt kunne nikke genkendende til, at elevers afdækning af fortællerposition med videre er en stor didaktisk udfordring. Det vil derfor være højst relevant at udvikle didaktiske genveje og løsningsforslag, som kan hjælpe lærerne i praksis; et foreløbigt forsøg på dette er fremlagt i Skriver (2010), men vil uden tvivl kunne udvikles langt bedre på baggrund af yderligere empirisk data, som evt. vil kunne bidrage til at tydeliggøre, hvilke aspekter af problemfeltet, der især volder eleverne forståelses- 
vanskeligheder. Det vil naturligvis variere fra elev til elev, ikke desto mindre er jeg overbevist om, at man vil kunne finde en række fællesnævnere og på den baggrund opstille kvalificerede didaktiske genveje for lærere og elever.

Den særlige litteraturdidaktiske udfordring, som blev tydelig under observationerne af, hvordan variablerne den dybtgående personskildring og den bredt udfoldede verden påvirkede undervisningen, nemlig at få eleverne til at foretage springet fra referat til analyse, er - det er i hvert fald mit indtryk fra mange samtaler med dansklærere og fra egen undervisning - en gammel kending blandt undervisere i litteratur. Observationen af gruppearbejdet synliggjorde derudover, hvordan det omfattende refererbare felt i H.C. Andersens Lykke-Peer gjorde det muligt for eleverne billedligt talt at krybe i ly for analysen ved at bruge al tiden på at referere de mangfoldige detaljer i persongalleriet og tekstens verden. Den generelle problematik forstærkes i forhold til elevernes arbejde med romaner, fordi genrens længde gør det muligt for forfatteren at uddybe disse områder ganske massivt i forhold til fx noveller. På den baggrund kunne det i et romandidaktisk perspektiv være interessant at undersøge, hvad der findes af litteratur, som belyser springet fra referat til analyse, og hvilke strategier dansklærerne i praksis anvender.

Den observerede lærer gjorde ganske meget ud af at fastholde elevernes fokus på det analytiske niveau i selve klasserumsinteraktionen. Det har uden tvivl betydning. For med sin insisterende spørgen holdt han konsekvent døren åben for det analytiske rum, eleverne skal vinde fortrolighed med for at leve op til læreplanens krav og ikke mindst for at kunne forholde sig reflekteret til tekster i deres fremtidige liv.

Det interessante spørgsmål i den forbindelse er naturligvis, hvad man yderligere kan gøre. Inspireret af Haugsted (2004) kunne man overveje, om det ikke var en mulighed systematisk at gøre selve genren 'analytisk litteratursamtale' til genstand for undervisning. Det ville måske kunne hjælpe eleverne til at udvikle en mere indgående og nuanceret forståelse af, hvordan man diskuterer litteratur, herunder litterære karakterer, med analytisk præcision. For mens de højt præsterende elever relativt hurtigt tilegner sig den analytiske diskurs, kan det for mange af de øvrige elever være forbundet med store vanskeligheder.

\section{Referencer}

Andersen, H.C. (1870/1984). Lykke-Peer. København: Gyldendal.

Bundgsgaard, J. \& Hansen, T.I. (2010): Processer i undervisningen: Om brugerdreven innovation af digitale procesværktøjer. Leremiddeldidaktik, 4 (4), 18-27.

Cohen, L., Manion, L. \& Morrison, K. (2007). Research Methods in Education. London \& New York: Routledge.

Haugsted, M.T. (2004). Mundtlighed og didaktik. I K. Schnack (Red.): Didaktik på kryds og tværs (s. 345-372). København: Danmarks Pædagogiske Universitets Forlag.

Hopkins, D. (2009). A Teacher's Guide to Classroom Research (4. udg.). Berkshire: McGraw-Hill. 
Sinclair, J. \& Coulthard, M. (1975). Towards an analysis of discourse: The English used by teachers and pupils. London: Oxford University Press.

Skriver, S. (2010). Romanen i undervisningen. I J. Fogt \& T. Thurah (Red.): Ny litteraturdidaktik (s. 123-150). København: Gyldendal.

Wegerif, R. (2004): The role of educational software as a support for teaching and learning conversations. Computers \& Education. 43 (1-2), 179-191. 